\title{
Kecemasan Siswa pada Mata Pelajaran Matematika (Student Anxiety in Mathematics Subjects)
}

\author{
Novita Maulidya Jalal \\ Fakultas Psikologi, Universitas Negeri Makassar \\ e-mail: novitamaulidya@yahoo.com
}

\begin{abstract}
The purpose of this research is to find out how mathematics anxiety can occur in students? The research method used is library research where in collecting data information with documentation techniques, namely looking for data about relevant matters from various kinds in libraries such as journals, documents, books, magazines, news. From the 16 sources obtained, the most relevant ones were selected. The results showed that based on the results of the study, it could be concluded that mathematics anxiety could occur due to low confidence in learning mathematics (self-efficacy) which was influenced by student perceptions of mathematics, minimal frequency of learning mathematics, learning situations that are less conducive, a history of low mathematical abilities, increasingly complex material, and demands for learning outcomes must be satisfactory. The effects of Mathematics anxiety include an effect on cognitive, physical, attitudes, and even student learning outcomes. treatment that can be given is given psychological treatment and taught by probing-prompting learning with ethno-mathematical nuances.
\end{abstract}

Keyword: Anxiety, Students, Math

\begin{abstract}
Abstrak.Tujuan dari penelitian ini adalah untuk mengetahui gambaran kecemasan Matematika dapat terjadi pada siswa. Metode penelitian yang digunakan adalah penelitian kepustakaan dimana dalam mengumpulkan informasi data dengan teknik dokumentasi yaitu mencari data mengenai hal-hal yang relevan dari berbagai macam yang ada di perpustakaan seperti jurnal, dokumen, buku, majalah, berita. Dari sumber yang didapatkan, kemudian dipilih yang paling relevan. Hasil penelitian menunjukkan bahwa kecemasan matematika dapat terjadi akibat rendahnya keyakinan dalam belajar matematika (self-efficacy) yang dipengaruhi oleh persepsi siswa tentang matematika, rendahnya frekuensi belajar matematika, situasi pembelajaran yang kurang kondusif, riwayat kemampuan matematis yang rendah, materi yang semakin kompleks, dan tuntutan hasil belajar harus memuaskan. Dampak yang ditimbulkan dari kecemasan Matematika antara lain berpengaruh pada kognitif, fisik, sikap, bahkan hingga hasil belajar Matematika siswa. Dengan demikian, penanganan yang dapat diberikan yaitu diberikan penanganan psikologis serta diajar dengan pembelajaran probing-prompting bernuansa etnomatematika.
\end{abstract}

Kata Kunci: Kecemasan, Siswa, Matematika 


\section{PENDAHULUAN}

Manusia sebagai makhluk yang memiliki kecerdasan kognitif akan selalu memperoleh pendidikan dalam kehidupannya, baik pendidikan formal, pendidikan informal, maupun pendidikan nonformal. Melalui pendidikan manusia dapat memperoleh pengetahuan, keterampilan, dan kebiasaan yang diturunkan dari satu generasi kegenerasi berikutnya melalui pengajaran, pelatihan, atau penelitian.

Negara Republik Indonesia melalui tujuan Pendidikan Nasional Indonesia berdasarkan UU no. 20 Tahun 2003 atau UU Sisdiknas berupaya untuk mengembangkan kemampuan dan membentuk watak serta peradaban bangsa yang bermartabat dalam rangka mencerdaskan kehidupan bangsa, bertujuan untuk berkembangnya potensi peserta didik agar menjadi manusia yang beriman dan bertakwa kepada Tuhan Yang Maha Esa, berakhlak mulia, sehat, berilmu, cakap, kreatif, mandiri, dan menjadi warga negara yang demokratis serta bertanggung jawab. Tujuan tersebut kemudian mewarnai dunia pendidikan di Indonesia, salah satunya melalui mata pelajaran yang disiapkan bagi anak didik.

Susanto (2013) menyatakan bahwa Matematika merupakan salah satu disiplin ilmu dan berargumentasi, memberikan kontribusi dalam penyelesaian masalah seharihari dan dalam dunia kerja, serta memberikan dukungan dalam pengembangan ilmu pengetahuan dan teknologi. Cockroft (dalam Shadiq, 2007) menyatakan bahwa akan sangat sulit atau mustahil ketika manusia menjalani kehidupan normal di dunia tanpa menggunakan matematika. Dengan demikian, matematika ini kemudian menjadi kebutuhan yang harus dipenuhi bagi setiap individu salah satunya dijenjang pendidikan manusia.

Matematika sebagai salah satu ilmu pengetahuan yang penting, pada kenyataannya, juga menjadi salah satu mata pelajaran yang dianggap sulit oleh sebagian besar siswa. Hal tersebut dapat disebabkan karena matematika merupakan materi pelajaran yang sifatnya abstrak, penuh angka, rumus, dan memerlukan latihan. Selain itu, materi pelajaran yang sulit disertai teknik pengajaran yang monoton menyebabkan siswa merasa mudah bosan untuk belajar, sehingga berdampak pada rendahnya pemahaman siswa pada materi pelajaran matematika. Kondisi tersebut kemudian berdampak pada rendahnya hasil belajar siswa, sehingga siswa kemudian mudah merasa cemas ketika menghadapi mata pelajaran matematika (Ekawati,2015). Sejalan dengan pendapat Yusof dan Tall (Auliya, 2016) menyatakan bahwa kecemasan matematika akan timbul akibat sikap negatif terhadap matematika secara berulang kali timbul saat peserta didik mengalami kesulitan dalam menyelesaikan soal atau ketika ujian.

Luo, dkk (2009) menjelaskan defenisi kecemasan matematika sebagai suatu reaksi suasana hati yang tidak sehat,dimana reaksi tersebut terjadi saat individu menghadapi mata pelajaran matematika yang membuat individu itu merasakan kepanikan, kepasrahan, kegelisahan, serta beberapa reaksi psikologi, 
seperti berkeringat pada wajah, mengepalkan tangan, sakit, muntah, bibir kering, dan pucat. Defenisi tersebut sejalan dengan pendapat Bursal dan Paznokas (Gresham, 2010) bahwa kecemasan matematika adalah keadaan tidak berdaya dan panik ketika diminta untuk mengerjakan tugas matematis.

Clute dan Hembree (dalam Vahedi dan Farrokhi,2011) menemukan bahwa siswa dengan kecemasan matematika yang tinggi memiliki prestasi belajar matematika yang rendah. Hasil penelitian Ashcraft dan Faust (Auliya,2016) juga menyatakan bahwa kecemasan matematika yang tinggi akan mengakibatkan kemampuan berhitung yang rendah, pengetahuan yang kurang mengenai matematika, dan ketidakmampuan dalam menemukan strategi khusus dan hubungan dalam bidang matematika. Dengan demikian, peneliti tertarik ingin mengetahui "Bagaimana kecemasan matematika dapat terjadi pada siswa?"

\section{METODE}

Studi dimulai dengan sistemtis untuk mengidentifikasi jurnal online mengenai Kecemasan Siswa pada Mata Pelajaran Matematika. Peneliti menggunakan metode telaah pustaka (library research). Sarwono (dalam Sari,2020) menyatakan bahwa penelitian kepustakaan adalah studi yang mempelajari berbagai buku referensi serta hasil penelitian sebelumnya yang sejenis yang berguna untuk mendapatkan landasan teori mengenai masalah yang akan diteliti. Kuhlthau (dalam Mirzaqon dan Purwoko, 2017) memaparkan bahwa terdapat beberapa langkah- langkah dalam penelitian kepustakaan yakni: 1. Pemilihan topik, 2. Eksplorasi informasi, 3. Menentukan fokus penelitian, 4. Pengumpulan sumber data, 5. Persiapan penyajian data, dan 6 . Penyusunan laporan. Penelitian ini menganalisa database elektronik google scholar dan sciencedirect dengan kata kunci Kecemasan Siswa pada Mata Pelajaran Matematika.

Kriteria inklusi pada studi ini adalah hanya pada studi terkait dengan Kecemasan Siswa pada Mata Pelajaran Matematika Analisis data digunakan untuk menjawab pertanyaan utama dalam penelitian, yaitu : "Bagaimana gambaran Kecemasan Siswa pada Mata Pelajaran Matematika?". Tujuan utama dalam penelitian ini adalah untuk mengeksplorasi, merangkum, dan melakukan sintesis pada litertur yang telah ada dalam memahami "Bagaimana kecemasan Matematika dapat terjadi pada siswa?".

\section{HASIL DAN PEMBAHASAN}

\section{Hasil}

Hasil penelitian dilakukan dengan menganalisa 10 jurnal terkait Kecemasan Siswa pada Mata Pelajaran Matematika berikut:

Tabel 1. Hasil penelitian terkait Kecemasan Siswa pada Mata Pelajaran Matematika

\begin{tabular}{|l|lr|}
\hline \multicolumn{2}{|c|}{ Judul Penelitian } & \multicolumn{2}{|c|}{ Hasil } \\
\hline Risma Nurul & Hasil penelitian \\
Auliya. & 2016. & menunjukkan $r$ bahwa \\
Kecemasan & & terdapatrremasan \\
Matematika dan & matematika berpengaruh \\
Pemahaman & & signifikan terhadap \\
Matematis & & kemampuan pemahaman \\
& & matematis peserta didik \\
\hline Paulus Roy & Memberikan definisi dan \\
Saputra.2014. & bentuk, kecemasan juga \\
Kecemasan & bisa dikurangi dengan \\
\hline
\end{tabular}




\begin{tabular}{|c|c|}
\hline $\begin{array}{l}\text { Matematika dan } \\
\text { Cara } \\
\text { Menguranginya } \\
\text { (Mathematic } \\
\text { Anxiety And How } \\
\text { To Reduce It) }\end{array}$ & $\begin{array}{l}\text { langkah-langkah yang } \\
\text { bisa dilakukan sesuai } \\
\text { dengan hasil penelitian } \\
\text { tokoh maupun akademisi } \\
\text { di bidang pendidikan dan } \\
\text { psikologi. Beberapa } \\
\text { langkah tersebut kiranya } \\
\text { dapat mengurangi } \\
\text { kecemasan yang ada } \\
\text { untuk menciptakan } \\
\text { suasana pembelajaran } \\
\text { yang kondusif, } \\
\text { menyenangkan dan } \\
\text { berpusat pada siswa. }\end{array}$ \\
\hline $\begin{array}{l}\text { Fajar Riski , } \\
\text { Indiana Marethi , } \\
\text { Isna } \\
\text { Rafianti.2019. } \\
\text { Pengaruh } \\
\text { Kecemasan } \\
\text { Matematika } \\
\text { Terhadap } \\
\text { Kemampuan } \\
\text { Pemecahan } \\
\text { Masalah Siswa Di } \\
\text { Sma (The Effect of } \\
\text { Mathematical } \\
\text { Anxiety } \\
\text { Students 'Problem } \\
\text { Solving Ability In } \\
\text { High School) }\end{array}$ & 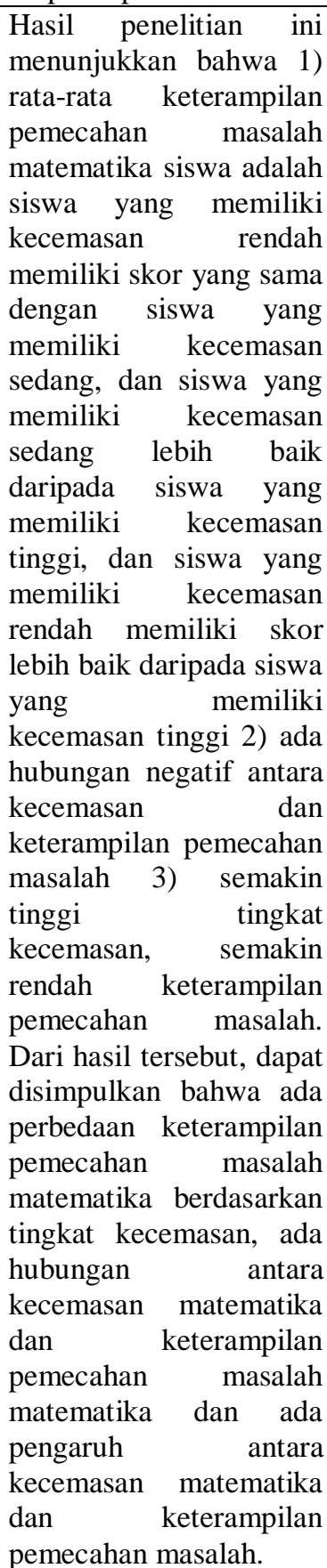 \\
\hline $\begin{array}{lr}\text { Natalia } & \text { Rosalina } \\
\text { Rawa } & \text { dan }\end{array}$ & $\begin{array}{ll}\text { Dari hasil penelitian } \\
\text { diperoleh }\end{array} \quad \begin{array}{r}\text { deskripsi } \\
\text { den }\end{array}$ \\
\hline
\end{tabular}

\begin{tabular}{|c|c|}
\hline $\begin{array}{l}\text { uputu Agus Eka } \\
\text { Mastika } \\
\text { Yasa.2016. } \\
\text { Kecemasan } \\
\text { Matematika Pada } \\
\text { Mahasiswa } \\
\text { Pendidikan Guru } \\
\text { Sekolah Dasar }\end{array}$ & 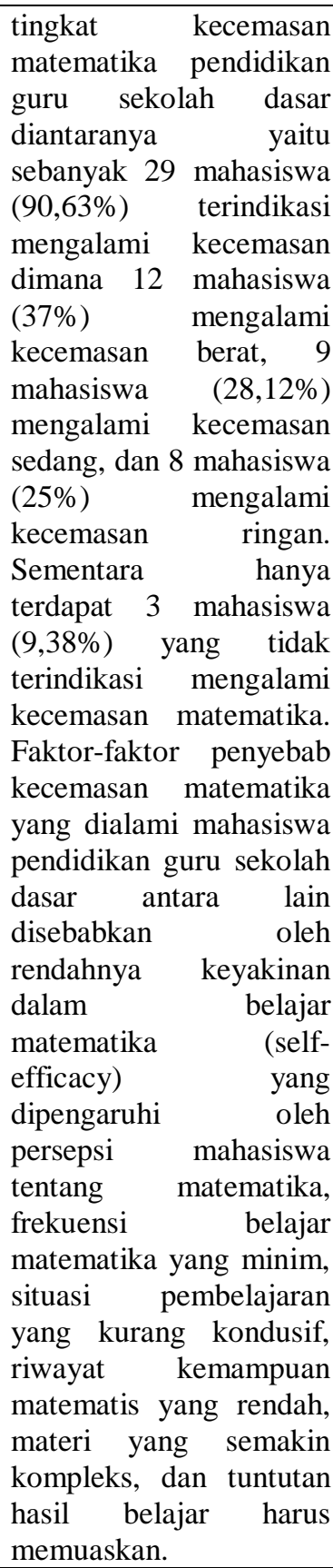 \\
\hline $\begin{array}{l}\text { Himmatul Ulya, } \\
\text { Ratri } \\
\text { Rahayu.2017. } \\
\text { Pembelajaran } \\
\text { Etnomatematika } \\
\text { untuk } \\
\text { Menurunkan } \\
\text { Kecemasan } \\
\text { Matematika }\end{array}$ & $\begin{array}{lr}\text { Hasil } & \text { penelitian } \\
\text { menunjukkan } & \text { bahwa } \\
\text { rata-rata kecemasan } & \text { katematika peserta didik } \\
\text { matem diajar } & \text { dengan } \\
\text { yang probing- } & \text { pembelajaran } \\
\text { prompting bernuansa } \\
\text { etnomatematika lebih } \\
\text { rendah dari rata-rata } \\
\text { kecemasan matematika } \\
\text { peserta didik yang diajar } \\
\text { dengan pembelajaran } \\
\text { ekspositori ran } \\
\text { kecemasan matematika } \\
\text { peserta didik yang } \\
\text { mengikuti pembelajaran } \\
\text { probing-prompting }\end{array}$ \\
\hline
\end{tabular}




\begin{tabular}{|c|c|}
\hline & $\begin{array}{l}\text { bernuansa } \\
\text { etnomatematika } \\
\text { mengalami penurunan } \\
\text { sebesar } 48 \% \text { dengan } \\
\text { kategori sedang. }\end{array}$ \\
\hline $\begin{array}{l}\text { Ulfiani Rahman, } \\
\text { Nursalam, M. } \\
\text { Ridwan } \\
\text { Tahir.2015. } \\
\text { Pengaruh } \\
\text { Kecemasan dan } \\
\text { Kesulitan Belajar } \\
\text { Matematika } \\
\text { Terhadap Hasil } \\
\text { Belajar } \\
\text { Matematika Pada } \\
\text { Siswa Kelas X Ma } \\
\text { Negeri } \\
\text { Watampone } \\
\text { Kabupaten Bone }\end{array}$ & 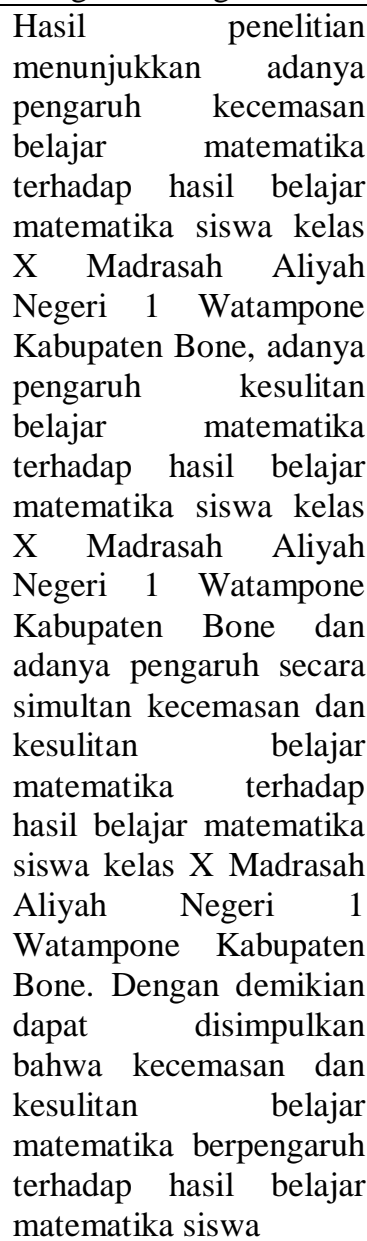 \\
\hline $\begin{array}{l}\text { Ahmad } \\
\text { Dzulfikar.2016. } \\
\text { Kecemasan } \\
\text { Matematika } \\
\text { Pada } \\
\text { Mahasiswa } \\
\text { Calon Guru } \\
\text { Matematika }\end{array}$ & $\begin{array}{l}\text { Dari hasil penelitian } \\
\text { diketahui bahwa secara } \\
\text { umum kecemasan } \\
\text { matematika mahasiswa } \\
\text { calon guru tersebut } \\
\text { berada pada level } \\
\text { sedang. } \\
\text { Apabila ditinjau dari } \\
\text { aspeknya, kecemasan } \\
\text { ketika mengajar dan } \\
\text { ketika tes matematika } \\
\text { merupakan kecemasan } \\
\text { yang tertinggi, bila } \\
\text { dibandingkan dengan } \\
\text { ketika mereka bekerja } \\
\text { dalam kelompok } \\
\text { matematika. in lebih } \\
\text { Kecemasan ini pada } \\
\text { dominan tampak pada } \\
\text { domain cognitive dan } \\
\text { mathematics } \\
\text { knowledge/understandin } \\
\text { g. Dimana mereka } \\
\text { merasa pengetahuan }\end{array}$ \\
\hline
\end{tabular}

\begin{tabular}{|c|c|}
\hline & $\begin{array}{l}\text { mereka masih kurang } \\
\text { dan mereka merasa } \\
\text { tidak cukup kompeten } \\
\text { dalam matematika atau } \\
\text { kemampuan } \\
\text { mengajarnya. }\end{array}$ \\
\hline $\begin{array}{l}\text { Amrina Rizta1 , } \\
\text { Luvi Antari.2019. } \\
\text { Tingkat } \\
\text { Mathematics } \\
\text { Anxiety Pada } \\
\text { Mahasiswa Calon } \\
\text { Guru Matematika }\end{array}$ & 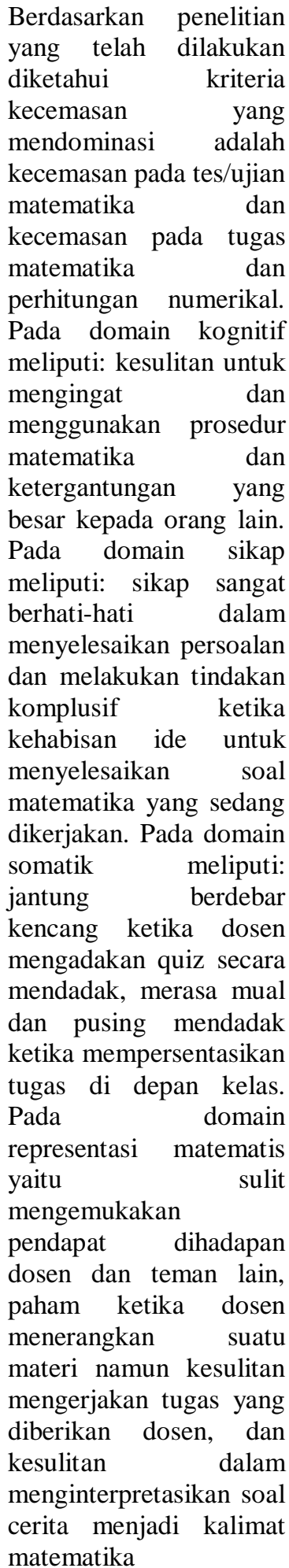 \\
\hline $\begin{array}{lr}\text { Wagetama. } & \text { I. } \\
\text { Disai., } & \text { Agoes } \\
\text { Dariyo., } & \text { Debora } \\
\text { Basaria } & \end{array}$ & $\begin{array}{l}\text { Hasil penelitian ini juga } \\
\text { menunjukkan bahwa } \\
\text { terdapat hubungan } \\
\text { signifikan positif antara }\end{array}$ \\
\hline
\end{tabular}




\begin{tabular}{|c|c|}
\hline $\begin{array}{l}\text { Yulianti.2017.Hub } \\
\text { ungan Antara } \\
\text { Kecemasan } \\
\text { Matematika dan } \\
\text { Self-Efficacy } \\
\text { Dengan Hasil } \\
\text { Belajar } \\
\text { Matematika Siswa } \\
\text { SMA X Kota } \\
\text { Palangka Raya }\end{array}$ & $\begin{array}{l}\text { self-efficacy dengan } \\
\text { hasil belajar Matematika } \\
\text { siswa SMA }\end{array}$ \\
\hline $\begin{array}{l}\text { Aminah } \\
\text { Ekawati.2015. } \\
\text { Pengaruh } \\
\text { Kecemasan } \\
\text { Terhadap Hasil } \\
\text { Belajar } \\
\text { Matematika Siswa } \\
\text { Kelas Vii Smpn } \\
13 \text { Banjarmasin }\end{array}$ & $\begin{array}{lr}\text { Hasil renelitian } \\
\text { menunjukkan } & \text { ada } \\
\text { pengaruh yang kuat } \\
\text { antara kecemasan } \\
\text { terhadap hasil belajar } \\
\text { matematika siswa kelas } \\
\text { VII SMPN } \\
\text { Banjarmasin }\end{array}$ \\
\hline
\end{tabular}

\section{Pembahasan}

Berdasarkan hasil penelitian diketahui bahwa kecemasan terhadap matematika dapat terjadi diakibatkan oleh beberapa faktor, antara lain rendahnya keyakinan dalam belajar matematika (self-efficacy) yang dipengaruhi oleh persepsi mahasiswa tentang matematika, frekuensi belajar matematika yang minim, situasi pembelajaran yang kurang kondusif, riwayat kemampuan matematis yang rendah, materi yang semakin kompleks, dan tuntutan hasil belajar harus memuaskan, Hasil penelitian ini sejalan dengan pendapat Smith (2004) bahwa kecemasan matematika dapat terjadi akibat peserta didik tidak pernah mengalami keberhasilan di kelas matematika.

Dampak yang ditimbulkan dari kecemasan Matematika antara lain:
a) Berpengaruh signifikan terhadap kemampuan pemahaman matematis peserta didik
b) keterampilan pemecahan masalah

c) hasil belajar matematika siswa

d) Pada domain kognitif meliputi: kesulitan untuk mengingat dan menggunakan prosedur matematika dan ketergantungan yang besar kepada orang lain.

e) Pada domain sikap meliputi: sikap sangat berhati-hati dalam menyelesaikan persoalan dan melakukan tindakan komplusif ketika kehabisan ide untuk menyelesaikan soal matematika yang sedang dikerjakan.

f) Pada domain somatik meliputi: jantung berdebar kencang ketika dosen mengadakan quiz secara mendadak, merasa mual dan pusing mendadak ketika mempersentasikan tugas di depan kelas.

g) Pada domain representasi matematis yaitu sulit mengemukakan pendapat dihadapan dosen dan teman lain, paham ketika dosen menerangkan suatu materi namun kesulitan mengerjakan tugas yang diberikan dosen, dan kesulitan dalam menginterpretasikan soal cerita menjadi kalimat matematika.

Hasil penelitian terebut sejalan dengan hasil penelitian Ashcraft (Sheffield dan Hunt, 2006) yang menyatakan bahwa siswa yang mengalami kecemasan matematika akan merasakan detak jantung yang lebih cepat atau kuat, keyakinan bahwa mereka tidak mampu untuk menyelesaikan masalah matematis, ataupun menghindari pelajaran matematika. Arem (dalam Zakaria, dkk, 2012) juga menyatakan bahwa peserta didik dengan kecemasan matematika yang tinggi cenderung 
kurang percaya diri dalam memahami konsep matematis.

Hal yang dapat diberikan untuk menanggulangi kecemasan matematika pada siswa antara lain:

a) Memberikan definisi dan bentuk, kecemasan juga bisa dikurangi dengan langkah-langkah yang bisa dilakukan sesuai dengan hasil penelitian tokoh maupun akademisi di bidang pendidikan dan psikologi.

b) Kecemasan matematika peserta didik yang diajar dengan pembelajaran probingpromptingbernuansa etnomatematika lebih rendah dari rata-rata kecemasan matematika peserta didik yang diajar dengan pembelajaran ekspositori dan kecemasan matematika peserta didik yang mengikuti pembelajaran probingprompting bernuansa etnomatematika.

Woodard (dalam Auliya, 2016) juga memaparkan beberapa teknik yang dapat digunakan untuk mengurangi kecemasan matematika, antara lain: 1) Menciptakan lingkungan kondusif bagi pembelajaran matematika, 2) Menggunakan kelompok kooperatif dapat membantu peserta didik untuk memahami masalah, 3) Mengajar dengan pelan, serta 4) Memberikan pembelajaran tambahan.

\section{SIMPULAN (PENUTUP)}

Berdasarkan hasil penelitian dapat disimpulkan bahwa kecemasan matematika dapat terjadi akibat rendahnya keyakinan dalam belajar matematika (self-efficacy) yang dipengaruhi oleh persepsi mahasiswa tentang matematika, frekuensi belajar matematika yang minim, situasi pembelajaran yang kurang kondusif, riwayat kemampuan matematis yang rendah, materi yang semakin kompleks, dan tuntutan hasil belajar harus memuaskan.

Dampak yang ditimbulkan dari kecemasan Matematika antara lain berpengaruh pada kognitif, fisik, sikap, bahkan hingga hasil belajar Matematika siswa. Dengan demikian, penanganan yang dapat diberikan yaitu diberikan penanganan psikologis serta diajar dengan pembelajaran probing-prompting bernuansa etnomatematika.

\section{DAFTAR PUSTAKA}

Auliya, R.N. 2016. Kecemasan Matematika Dan Pemahaman Matematis. Jurnal Formatif, 6(1): 12-22.

Disai,W.I., Dariyo,A.,\& Yulianti,D.B. 2017. Hubungan Antara Kecemasan Matematika Dan Self-Efficacy Dengan Hasil Belajar Matematika Siswa SMA X Kota Palangka Raya. Jurnal Muara: Ilmu Sosial,Humaniora, dan Seni, 1(2) (Online), https://journal.untar.ac.id/index.php/j mishumsen/article/view/799/0

Dzulfikar, A. 2016. Kecemasan matematika pada mahasiswa calon guru matematika. JMPM: Jurnal Matematika dan Pendidikan Matematika,1(1). (Online),http://journal.unipdu.ac.id:8 080/index.php/jmpm/article/view/50 $\underline{8}$

Ekawati, A. 2015.Pengaruh Kecemasan Terhadap Hasil Belajar Matematika Siswa Kelas VII SMPN 13 Banjarmasin. Math Didactic: Jurnal Pendidikan Matematika 1(3). 
Riski, F., Marethi, I.,\& Rafianti, I. 2019. Pengaruh Kecemasan Matematika Terhadap Kemampuan Pemecahan Masalah Siswa Di SMA (the effect of mathematical anxiety of students 'problem solving ability in high school). GAUSS: Jurnal Pendidikan Matematika, 2(2),(Online) http://dx.doi.org/10.30656/gauss.v2i $\underline{2.175}$

Gresham, G. 2010. A Study Exploring Exceptional Education Mathematics Anxiety. IUMPST: The Journal Vol. 4.

Luo, W., dan Luo. 2009. Investigation And Analysis Of Mathematics Anxiety In Middle School Students. Journal of Mathematics Education 2(2):12-19.

Mirzaqon. T, A dan Purwoko, B. 2017. Studi Kepustakaan Mengenai Landasan Teori dan Praktik Konseling Expressive Writing. Jurnal BK Unesa, 8(1).

Rahman, U., Tahir, N., \& Ridwan, M. 2015. Pengaruh Kecemasan Dan Kesulitan Belajar Matematika Terhadap Hasil Belajar Matematika Pada Siswa Kelas X MA Negeri 1 Watampone Kabupaten Bone.MAPAN: Jurnal Matematika dan Pembelajaran ,3(1), (Online), http://journal.uinalauddin.ac.id/index.php/Mapan/artic le/view/2752

Rizta, A.,\& Antari, L. 2019. Tingkat Mathematics Anxiety Pada Mahasiswa Calon Guru Matematika. Jurnal Pendidikan Matematika, 13(1):9-20.

Rosalina, N.R.,\& Yasa, U.A.E.M. 2016. Kecemasan Matematika Pada Mahasiswa Pendidikan Guru Sekolah Dasar. Journal of Education Technology,2(2), (Online) https://ejournal.undiksha.ac.id/index. php/JET/article/view/16180

Saputra, P.R. 2014. Kecemasan Matematika Dan Cara Menguranginya
(Mathematic Anxiety And How To Reduce It). Phytagoras: Jurnal Program Studi Pendidikan Matematika,3(2), (Online) https://www.journal.unrika.ac.id/ind ex.php/jurnalphythagoras/article/vie $\underline{w / 590}$

Sari,M. 2020. Penelitian Kepustakaan (Library Research) dalam Penelitian Pendidikan IPA. NATURAL SCIENCE: Jurnal Penelitian Bidang IPA dan Pendidikan IPA, 6(1):41-53.

Shadiq, F. 2007. Apa dan Mengapa Matematika Begitu Penting. Yogyakarta: Widyaiswara PPPPTK Matematika.

Sheffield, D. \& Hunt, T. 2006. How does anxiety influence maths performance and what can we do about it?. MSOR Connections, 6(4).

Smith, M. R. 2004. Math Anxiety: Causes, Effects, and Preventative Measures. A Senior Thesis submitted in partial fulfillment of the requirements for graduation in the Honors Program, Liberti University.

Susanto, A. 2013. Teori Belajar \& Pembelajaran di Sekolah Dasar. Jakarta: Prenadamedia Group.

UU no. 20 Tahun 2003 atau UU Sisdiknas.

Ulya, H. \& Rahayu, R. 2017. Pembelajaran Etnomatematika Untuk Menurunkan Kecemasan Matematika. Jurnal Mercumatika : Jurnal Penelitian Matematika dan Pendidikan Matematika, 2(1):16-23.

Vahedi, S. \& Farrokhi, F. 2011. A Confirmatory Factor Analysis Of The Structure Of Abbreviated Math Anxiety Scale. Iran Journal Psychiatry, 6:47-53.

Zakaria, E., Zain, N. M., Ahmad, N.A., \& Erlina, A. 2012. Mathematics Anxiety And Achievement Among Secondary School Students. 
Novita.M.J, Kecemasan Siswa Pada Mata Pelajaran....

American Journal of Applied

Sciences, 9 (11). 